\title{
2. Os sobreviventes da noite e a persistência do passado contra o
} Caos

\author{
Ubiratã Souza
}

\section{SciELO Books / SciELO Livros / SciELO Libros}

SOUZA, U. Os sobreviventes da noite e a persistência do passado contra o Caos. In: Entre palavras e armas: literatura e guerra civil em Moçambique [online]. São Bernardo do Campo, SP: Editora UFABC, 2017, pp. 77-124. ISBN: 978-85-68576-92-2. https://doi.org/10.7476/9788568576922.0003.

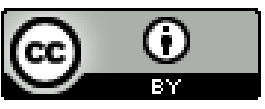

All the contents of this work, except where otherwise noted, is licensed under a Creative Commons Attribution 4.0 International license.

Todo o conteúdo deste trabalho, exceto quando houver ressalva, é publicado sob a licença Creative Commons Atribição 4.0.

Todo el contenido de esta obra, excepto donde se indique lo contrario, está bajo licencia de la licencia Creative Commons Reconocimento 4.0. 


\section{Os sobreviventes da noite e a persistência do passado contra o Caos}

\subsection{Ungulani Ba Ka Khosa na literatura moçambicana}

Ungulani Ba Ka Khosa é hoje considerado uma das mais prolíficas vozes da literatura moçambicana em prosa, ao lado de nomes como Mia Couto e Paulina Chiziane, para citar alguns representativos exemplos. Khosa é autor de cinco romances, Ualalapi (1987), No reino dos abutres (2002), Os sobreviventes da noite (2005), Choriro (2009) e Entre as memórias silenciadas (2013), e de dois livros de contos, Orgia dos loucos (1990) e Histórias de amor e espanto (1999). Sua magnum opus, no entanto, é justamente Ualalapi, considerada "uma das obras maiores da ficção moçambicana", como nomeou Maria Fernanda Afonso (2004, p. 297). A fortuna crítica de Ungulani começa a tomar corpo nas últimas décadas e a traçar certo perfil da obra desse escritor. Algum reconhecimento está a ser-lhe atribuído em momentos como a outorga da comenda da Ordem Infante Dom Henrique pelo governo português a ele e à Paulina Chiziane, nos princípios de 2014.

Francisco Esaú Cossa nasceu em 1957 na cidade Inhaminga, na província de Sofala. Lá fez seus primeiros estudos, e o ensino secundário o fez uma parte na então cidade de Lourenço Marques e outra parte na província da Zambézia, onde passou toda a sua adolescência. Com onze anos, em 1968, submeteu-se a um ritual iniciático em que recebeu o nome de um seu tio-avô, Hungulani Ba Ka Khosa 
Banhinhgue (que, segundo ele, significaria "diminuam os khosas, que são muitos"), do qual ele extrairia o nome que assinaria a partir do momento em que se tornou escritor. Em 1977 vai para Maputo onde recebe a determinação do governo de fazer um curso intensivo de formação de professores. Em 1978 é direcionado à cidade de Lichinga, na província do Niassa, para dar aulas nos campos de reeducação. Lá assiste a episódios terríveis de violência física e simbólica perpetrados pelas forças do jovem Estado moçambicano contra detentos aprisionados por vários motivos, desde acusações de crimes, a dissidências ideológicas do partido (transgressões imputadas aos então chamados de "reacionários" ou "renitentes", dependendo do caso), e até desvios dos padrões morais exigidos pela FRELIMO, nos quais se enquadravam, por exemplo, prostitutas, alcóolatras, desempregados (os chamados então de "improdutivos", mormente após a "Operação Produção", de 1983). Essa temporada do escritor no Niassa configuraria aquilo que Khosa define com "ruptura com o Poder" (LABAN, 1998, p. 1051; SAÚTE, 2010, p. 358; CHABAL, 1994, p. 310). De volta a Maputo em 1980, Khosa passa pelo funcionalismo público até se tornar membro e funcionário da Associação dos Escritores Moçambicanos. Em 1984 se associa a um grupo para a fundação da revista Charrua, marcada por definir uma geração, composta por nomes como Eduardo White, Aldino Muianga, Marcelo Panguana, que questionavam, ainda que de forma reticente, a literatura oficial revolucionária comprometida com as esferas do poder político.

Em 1987 lança Ualalapi, obra controversa que inscreveria o nome de Ungulani Ba Ka Khosa na literatura moçambicana por ter carreado atrás de si um rastro de polêmicas. Segundo depoimento do próprio autor a Michel Laban (1998, p. 1067), seu primeiro impulso teria sido publicar um capítulo, "A morte de Mputa”, nas páginas da "Gazeta de artes e letras", caderno que encerrava números alternados da revista Tempo (1970 - 2008). A proposta teria sido feita ao seu 
diretor, à altura, o Albino Magaia, que recusou instantaneamente a publicação do capítulo, segundo Khosa, porque era demasiado "agressivo". Khosa replica o argumento em sua entrevista, desta vez atribuindo-o a Rui Nogar, que teria feito o mesmo comentário - "agressivo" - em relação a Ualalapi, quando este, já em forma de livro editado pela primeira vez pela coleção "Início" da Associação dos Escritores Moçambicanos, recebeu uma apresentação do poeta. À publicação de Ualalapi ter-se-ia seguido uma grande polêmica por conta das implicações históricas relativas às opções estéticas contidas na obra: Ualalapi tratava centralmente da figura a um tempo histórica e mítica de Ngungunhane (ou Mudungazi, antes da entronização), último soberano do chamado Império de Gaza, derradeira instituição política endógena derrotada por Portugal para o estabelecimento da colonização efetiva do sul de Moçambique após a Partilha da África no final do século XIX. Com efeito, uma recensão publicada no jornal Domingo, de Maputo, em 6 de setembro de 1987, escrita por Adelino Jorge Fernandes, caracteriza Ualalapi como "um SIDA histórico", acusando-o de plágio por incrustar excertos de documentos históricos na malha do texto, mescladas com trechos narrativos autorais próprios sem a devida notação referencial. Segundo o resenhista (FERNANDES, 1987, s/p):

"Ualalapi" além de ser um talento, é também um erro imperdoável, porque o autor rebaixa a projecção social e dá uma projecção ideológica falsa de Ngungunhane. Ungulani preocupou-se somente em citar de uma ou outra maneira os defeitos de Ngungunhane, enquanto que as glórias que "pesam” sobre ele são maiores. Ungulani, deste modo, questiona Ngungunhane e, como se não bastasse, ainda caminha para o pior: deturpa a imagem histórica de Ngungunhane.

O debate entre a história constrangida pela literatura em relação ao Ualalapi não é uma petição de princípio da crítica naquele momento de lançamento da obra, mas, sim, uma indagação invocada 
pela própria obra e da qual ela nunca mais se livraria. Cumpriria à crítica analítica, no entanto, buscar compreender com precisão as condicionantes estruturais da estética da obra que provocam tamanha cizânia entre a literatura e a história. Afinal, todo o tema da obra já exige, por princípio, uma reflexão que foge ao domínio da literatura, o que é causado pela intensa referencialidade ao dado histórico de Gaza. Ao demandar um conhecimento histórico grandioso, o leitor estará inserido nas dinâmicas que envolveram o estabelecimento definitivo do poder colonial português no território moçambicano no final do século XIX. Gaza, no entanto, faz referência a acontecimentos in statu quo ante aos interesses imperialistas dos portugueses, especificamente da forma como se encontraram influenciados pelo espírito de disputa entre potências durante a partilha da África na segunda metade do século XIX e início do XX e ao mesmo tempo a toda elaboração de uma história nacionalista perpetrada pelo novo Estado moçambicano. O momento político e histórico em que a obra foi lançada, no entanto, não permitiu a nenhum crítico literário lançar mão dessa abordagem sobre a obra, e se de um lado ela acabou conservando a pecha de "agressiva", por outro lado, na pior das hipóteses, não se costuma atentar muito à dimensão crítica atual da obra, por considerá-la de temática "pré-colonial".

\subsection{Uma narrativa ensandecida}

Um primeiro contato com Os sobreviventes da noite ${ }^{7}$ decerto deve revelar algumas dificuldades para o leitor que merecem atenção enquanto características do texto. Composto em seis capítulos, o romance é realizado como uma massa textual densa, com parágrafos

7 Utilizou-se a segunda edição da obra: KHOSA, Ungulani Ba Ka. Os sobreviventes da noite. Maputo: Texto Editores, 2008, doravante chamada de OSN. 
recorrentemente enormes, podendo custar páginas e páginas, e com uma notação de pontuação e ortográfica bastante incomum. Isso faz com que o texto escorra pelas páginas num ritmo alucinante e absolutamente próprio, sendo preciso buscar a construção do sentido decifrando a densidade da massa textual, em que enredos, as personagens, as ações e situações estão dispersos de modo frenético ao longo da obra. Resta ao leitor, portanto, compor paulatinamente os cenários, a vida das personagens e suas histórias, combinando e recombinando trechos esparsos que se conectarão somente após a leitura do todo. A divisão do texto por capítulos pode acabar por nem ser muito significante: na maioria das vezes representa uma intermitência, que garante certo fôlego, mas que pouco contribui para alterar o fluxo alucinante da narrativa. Esse fluxo, inclusive, é causado por uma liberdade de temas e assuntos enorme: nenhum tema se impõe, nenhum assunto é desenvolvido de acordo com algum rigor muito lógico. Certo dado do tempo presente da narrativa invoca certo dado da história da personagem, que intercepta a narrativa em tempo presente e ganha sua vez na economia da obra. Mas isso não é garantia nenhuma: as histórias interceptam-se umas às outras, vão e retornam com uma fluidez acachapante.

Essa forma complexa de narrar abriga uma história igualmente complexa. Estamos num acampamento de campanha de guerra e teremos contato com alguns dias de uma rotina aparentemente simples e monótona, mas que será o acesso para toda uma história mais ampla, em que conseguiremos obter informações a respeito da entrada de cada personagem nessa guerra, suas trajetórias individuais e suas mais remotas origens. Também acessaremos diversos momentos cruciais para a compreensão de que guerra era essa, e como cada percurso individual teria sido atravessado por tal acontecimento. Certo tom de horror e estupefação acompanha cada descrição, de cada ato ou personagem, que, na maioria das vezes, estão postos no sinal negativo: tudo está solapado e destruído pela guerra, que é o sinal constante que a tudo atravessa. Uma forma caótica de narrar o caos, por suposto. 
Essa forma caótica causada pela fluidez entre temas e assuntos, que garante à narrativa um fluxo desenfreado, está aqui sob a responsabilidade de uma voz narrativa que talvez seja a única força estética arbitrária dentro da malha textual. É essa voz quem nos fala com imensa onisciência do que bem entende, como num fluxo de consciência. Além de oscilar de um tempo a outro, sem prévias justificativas ou qualquer encadeamento sequencial, oscila também de uma personagem a outra, alterando o foco da narrativa, muitas vezes assumindo um discurso indireto livre, o que a faz perder o turno da fala, embaralhando ainda mais a organização dos dados.

Essa desordem na forma de narrar decerto está posta em função de uma tensão que persegue essa voz narrativa. Contar a história, para esse narrador, é um ato de imensa liberdade e, ao mesmo tempo, de constante preocupação. Isso porque ele está colocado num ponto equidistante entre aquele universo que pretende narrar e um universo do conhecimento racional e lógico, com o qual parece se debater constantemente. Nesse sentido, correntemente narra os acontecimentos localizando dados, características e espaços em relação a certo saber erudito aqui representado pela figura de "livros e compêndios" que, na maioria das vezes, são incapazes de atribuir alguma significação que venha explicar os fenômenos dos quais se aproxima com o objetivo de descrever e narrar. Às figuras dos "compêndios", soma-se certa preocupação em problematizar o uso da língua portuguesa para tratar dos acontecimentos e situações narradas. Vejamos, logo de início, quando quer demonstrar como estavam dispostos os garotos pelo acampamento no momento do repouso (OSN, p. 15):

Os troncos que protegiam as costas formavam um rectângulo que todos chamavam de curral, no sentido pejorativo do termo, pois, na verdade, não se tratava de curral, mas dum alpendre na vulgar designação que a língua portuguesa nos dá. E todos os que nele, curral, no dizer dos chefes se concentravam, 
formavam um tapete lamacento com vincos humanos desordenados de onde sobressaíam troncos, cabeças, pernas e braços. [...] Ao todo eram dez, onze, ou quinze, ninguém sabia ao certo, pois a mobilidade era de tal ordem que a aritmética rural dos dedos poucos davam à racional memorização.

Aí está posta certa crise com a aplicação da palavra "curral", segundo seu uso na língua portuguesa, e a busca por outra mais adequada àquela construção de troncos que o narrador parece ter dificuldade de nomear. Logo em seguida temos um conflito semelhante, desta vez não com a língua, mas sim com os números: "a aritmética rural dos dedos" não seria favorável a nenhuma memorização que mensurasse quantos meninos de fato havia naquele acampamento. "Ninguém sabia ao certo" quantos seriam. A palavra "rural" decerto opera como uma antecipação de um dado da origem daquelas pessoas que ocasionalmente tentassem calcular a quantidade de pessoas ali presentes: a aritmética "rural" seria incapaz de calcular. Há que se visualizar aí certa definição de um estabelecimento geográfico maior. Mas ainda não tratamos das origens.

A hesitação do narrador em definir objetos, homens, números e dados diante do caos parece ser tanta que produz contradições. Ao mesmo tempo que afirmava nesse início da obra que não seria possível mensurar quantos meninos havia no acampamento devido à impossibilidade de memorizar a quantia pela aritmética, logo mais consegue produzir um número, a despeito da dificuldade (OSN, p. 55):

Ao todo, e em números aproximados, pois a rotatividade, em função do inimigo e da morte, era elevada, o acampamento albergava umas cem almas. Maioritariamente uma população jovem que ia dos oito aos dezasseis anos.

O narrador encontra uma dificuldade e duas causas que impossibilitavam o cálculo: a dificuldade é a rotatividade, causada, por 
sua vez, pelo inimigo e pela morte. Os números aparecem "aproximados”, devido à morte como constante. Então, temos já desenhos desse acampamento e dessa guerra: tratava-se de uma guerra composta "maioritariamente" por crianças, cujo índice de mortalidade durante os conflitos deveria ser alto o suficiente para criar uma rotatividade que impossibilitaria o cálculo lógico por vias aritméticas.

Outra oportunidade de verificar o procedimento de afastamento equidistante de um universo racional da cultura ocidental e o universo que agora narra é quando se trata da história de Rosa (OSN, p. 40):

Ela cresceu naquilo que os compêndios da arquitectura designam de vila. Uma vila feita de vinte casas e oito edifícios de cimento milimetricamente distribuídas por quatro ruas de macadame. [...] Rosa não nasceu no hospital, e nunca em vida soube o que era uma cama de ferro e um colchão de algodão.

Nesse trecho pode-se perceber o conflito entre a estrutura urbanística que existia no local de crescimento de Rosa e a forma como essa estrutura poderia ser designada pelos "compêndios da arquitectura”. Ora, o pronome demonstrativo aplicado à estrutura urbanística, “aquilo", marca certa distância daquela estrutura: não é possível nomeá-la de modo individual, por isso atribui-se-lhe, pronominalmente, uma identidade vaga ${ }^{8}$. Da mesma forma, ao dizer que os compêndios de arquitetura é que designam a forma como "vila" se estrutura, o narrador não parece fazer questão de acolher essa designação, mas de deixar claro que é uma mera designação teórica, igualmente distante daquele universo. Também Rosa nunca soube o que era uma "cama de ferro" e um "colchão de algodão", mas, decerto, deveria ter sua forma de repouso que aqui não está explícita: o que está claro é que ela

8 Castilho e Elias (2012, p. 115) propõem que o pronome demonstrativo "aquilo" possa ser classificado como pronome de "identidade vaga", relacionado com os pronomes "aquele / aquela", de identidade precisa, e com o pronome "tal”, de alteridade. 
estaria distante de uma forma urbana de repouso, demasiada, cheia de detalhes para ser íntima do narrador (os acessórios predicativos, "de ferro", "de algodão", que o provem. Caso o narrador se apresentasse íntimo dos hábitos urbanos não bastaria dizer somente "cama" e “colchão", como menores qualificativos?)

Há outros trechos significativos em que essa voz narrativa constrói referências aos manuais e aos compêndios do conhecimento racional:

Aos que se apegam aos manuais de antropologia, a mãe de Sabonete poderia ser considerada poliandra, por ter como maridos os já designados seis combatentes. Mas a terrena verdade leva-nos a evitar tal nomeação por não se alicerçar em práticas seculares arrumadas nos poeirentos livros genericamente designados de "Usos e Costumes dos Povos tais e tais". (OSN, p. 19).

Aqui se impõe a oposição entre o conhecimento antropológico, que poderia designar a condição da mãe do menino Sabonete como "poliandria", e uma situação definida por ele como "terrena verdade", que contrariaria a tese antropológica. Ora, a situação da mãe de Sabonete "não estaria alicerçada" em práticas culturais ("usos e costumes dos povos"), mas, sim, seria uma condição imposta pela própria guerra - e isso é muito importante para desarmar um argumento provável de que a distância da cultura urbana fosse causada pela persistência da "tradição", ou seja, das culturas endógenas. Vale perceber certo desprezo que se incute na fala desse narrador ao chamar os manuais de "poeirentos livros". A retomada da expressão "usos e costumes" também pode se assentar sobre uma base crítica: faz referência a essa categoria folclorizante característica da antropologia colonial que tartamudeava ao conceder às práticas sociais dos povos colonizados o estatuto de "cultura" (THOMAZ, 2001, p. 58). Desse modo, o texto 
apontaria para a limitação dessa categoria antropológica de análise de laços parentais para o contexto da guerra.

Outro momento significativo em que a voz narrativa se debate sobre uma possível racionalidade que produzisse conclusões inadequadas é quando trata do fato de que a mesma Rosa houvesse se iniciado sexualmente pelo próprio tio (OSN, p. 49):

As puritanas e racionalmente preparadas almas podem pensar que a Rosa odiava o tio. Não. Para ela, o tio era o mestre dos segredos da alcova.

A voz narrativa então parece produzir uma expectativa sobre a recepção da relação incestuosa. Nesse momento, então, ele desloca um provável sentido do óbvio, classificando essa expectativa de "puritana" e "racionalmente preparada". Trata-se de questionar a compreensão do incesto de uma forma traumática para a moça como única viabilidade interpretativa, o que derivaria de mentes "puritanas" e de almas "racionalmente preparadas". Quer dizer, em que contexto, exatamente, o incesto pode produzir uma situação traumática? Não fica claro, no entanto, quais são essas "almas puritanas" que compreenderiam o incesto de forma traumática. $\mathrm{O}$ próprio leitor? $\mathrm{Ou}$ as pessoas do entorno de Rosa que, sabendo da relação incestuosa, supunham o ódio?

Juntamente com esse debate entre o conhecimento erudito e ocidental, que se encontra à distância do universo da guerra, e, portanto, transforma-se em incapaz de produzir deduções e constatações salutares a uma análise daquela situação, existe certo estupor por parte do narrador, que, igualmente, se espanta diante do caos - afinal, é justamente por essa causa que o narrador está numa posição equidistante entre um universo e outro. Essa situação caótica é definida constantemente sob o signo da desordem, da desorganização, do esfacelamento e da dissolução das coisas, inclusive dos ambientes e espaços. O espaço todo do acampamento é construído de uma forma "arquitectonicamente" desigual e assimétrica, conforme diz (OSN, p. 61): 
O acampamento parecia-se com uma aldeia apressadamente reconstruída após um vendaval. Os alpendres, ou casernas, ou currais, mal se sustinham nos pilares de troncos desalinhados; as palhotas, circulares e quadradas, eram assimetricamente distribuídas no espaço que lhes era reservado. As palhotas dos comandantes e suas concubinas apresentavam-se mais cuidadas por entre as árvores.

"Apressadamente reconstruída”, "desalinhados" e "assimétricos" são aspectos que adjetivam essa descrição. Claro, essas conclusões descritivas estão postas em relação a certa ideia aqui, não declarada, de uma aldeia cuidadosamente construída, alinhada e simétrica. Essa espécie de "ideal ausente" de aldeia dificilmente deve se referir a uma cidade urbana ao modelo ocidental, assunto que trataremos adiante. Mas ainda é possível perceber que, apesar da desordem confessada, certa organização ainda assim se sobressai: há um "espaço reservado" para a construção dos edifícios, que, por sua vez, podem ser "alpendres, casernas ou currais", e ainda "palhotas, circulares e quadradas". Há ainda os edifícios reservados aos "comandantes e suas concubinas", que, não ironicamente, são mais cuidados. Ou seja, parece que o caos estupefaciente de nosso narrador revela, em detalhe, certa forma de organização, como podemos ver (OSN, p. 16):

Por todo lado viam-se cadeiras partidas, mesas sem pés, sofás sem molas, bicicletas sem rodas, cadeiras de baloiço, canhões destruídos. E como que a coroar os estranhos objectos espalhados pelo terreiro, destacava-se um piano de teclas partidas à espera de uma sinfonia que jamais viria. No fundo, na chamada zona dos mortos, as caveiras acotovelavam-se, espantadas com sua sorte.

Ora, aqui novamente a estupefação é causada pela desordem de objetos dissolvidos na mais completa destruição. No entanto, destaca-se uma área reservada para o depósito de cadáveres, talvez 
alguma forma de sepultamento, de isolamento desses corpos: "a chamada zona dos mortos". O fato dessa voz narrativa frisar que essa "zona dos mortos" é assim "chamada" pelas pessoas ali presentes marca novamente certa distância em relação à descrição: o próprio narrador não absorve essa denominação, mas frisa que ela provém de certa anterioridade nominativa, que, podemos supor, tenha relações com a forma como os partícipes dessa guerra buscam organizar-se dentro da desordem.

Igualmente ao espaço, que na desordem parece assumir certa organização, parece existir certa rotina de trabalhos, marcada pelas horas dos dias (OSN, p. 55):

E na hora em que o sol torrava o acampamento, os guerreiros, em digestivas posições de predadores, roedores e ruminantes, estiravam-se nas sombras que aumentavam de espaço ao sabor análgico da suruma em momentos de repouso. Quem olhasse para o acampamento nas horas em que o sol fazia a diária descida à morte, angustiava-se com a desordem arquitectónica na ocupação das sombras.

Os guerreiros aqui em posições descritas de forma zoomórfica estão "estirados", e a sombra que produzem varia de tamanho, "aumentavam de espaço", devido ao efeito entorpecente da "suruma" (trata-se do uso fumígeno das folhas de Cannabis sativa, no Brasil conhecida como maconha). O uso dos verbos no pretérito imperfeito, "torrava”, "estiravam-se", "aumentavam", "angustiava-se”, atribui a esse hábito de estirar-se nas horas do ocaso um aspecto de duração iterativa, informando, desse modo, que o hábito se constitui numa rotina, com hora certa para acontecer: entre a hora que o "sol torrava o acampamento" até a hora que o "sol fazia a descida à morte". Além da descrição dos espaços e das rotinas, o estupor da voz narrativa parece se tornar agudo quando precisa narrar os acontecimentos dos campos de batalha. Aí, de forma enfática, seu repertório de erudição é apresentado como ineficiente para o trato da catástrofe, como se vê (OSN, p. 58): 
E eles destruíam tudo. Casas, pontes, igrejas e tudo o que se movia no espaço da catástrofe. E, no tresvario da destruição, não se limitavam somente a assassinar pessoas armadas e indefesas. Tinham que destruí-las, esquartejá-las, despedaçá-las. E, no gozo do espostejamento, laceravam os seios das mulheres, retalhavam as pernas e os braços dos homens, capavam jovens renitentes e velhos [...]. E tudo numa procissão anatómica de que não há memória nos compêndios empíricos e científicos compilados ao longo dos séculos.

Essa distância marcada entre o que se narra e uma forma lógica de compreensão e conhecimento poderia ser tomada aqui como um índice expressivo de uma situação comunicativa culturalmente ambígua, se levarmos em consideração o ambiente colonial que produziu a literatura em Moçambique. Essa situação comunicativa culturalmente ambígua já foi largamente estudada ${ }^{9}$, sobretudo quando as análises se centram na oposição literária à colonização e à hegemonia cultural desempenhada pelo colonizador. Nesse processo, a aproximação ao universo cultural colonizado é, por si só, um determinante de certo distanciamento da cultura ocidental letrada e racional, que, em muitos aspectos, é mostrada em sua insuficiência diante do contexto colonizado. No entanto, será a postura preocupada desse narrador de Os sobreviventes da noite um índice desse conflito próprio da literatura africana?

A configuração desse narrador de encruzilhada nos oferece alguns motivos para acreditar que não há muitas confluências entre a postura desse narrador e o antigo conflito da situação colonial

\footnotetext{
9 Vale aqui lembrar da proposta de Fanon para os "estágios" formativos das literaturas africanas em ambientes coloniais (2005, p. 46). Os estudos de Ana Mafalda Leite (2012), que buscam organizar a equação entre escrita e oralidade no universo das literaturas africanas, são também exemplos dessa dicotomia cultural que acompanha a configuração das literaturas africanas, se pensarmos em como o recurso às culturas acústicas residuais representam estratégias de oposição ao colonialismo e "resgate" de uma cultura oprimida (LOPES, 2003, p. 266).
} 
ambígua. A dissolução é a marca forte de qualquer descrição, de qualquer evento narrado. Assim, diante do caos da guerra, alguns resíduos culturais das culturas endógenas persistem, embora mutilados, e a cultura racional não consegue sequer produzir termos de análise pertinentes para aquela situação. No entanto, a mesma distância que esse narrador guarda entre a cultura racional e lógica, ocidental, está também posta em relação às culturas endógenas, embora persistentes no ambiente de guerra, mas igualmente dissolutas, como se vê (OSN, p. 112):

Mas no acampamento havia também outros hábitos que enroupavam e adereçavam os corpos, como amuletos e fios e peles e unhas e dentes de animais bravios e caseiros como os do homem, da galinha, do pato e das cabras, mas estes atavios a ninguém espantavam pois era uso e vezeiros tê-los na tenra idade em que os rituais mágicos-religiosos das incisões na pele entravam pelo corpo adentro, obrigando, a quem a elas se submetesse, a seguir os preceitos não escritos, mas religiosa e oralmente transmitidos pelos que ostentavam o dente do juízo.

O trecho demonstra que no acampamento ainda era possível observar a manipulação de objetos embutidos de significado social simbólico com efeitos em dimensões sobrenaturais. Esses usos de adereços estão postos naquele contexto como um "hábito" de "enroupar" e "adereçar", que tomam vez ao lado do uso distintivo de fardas e outras formas simbólicas. No entanto, a forma como esses dados são descritos de modo abstruso e passageiro, objetivamente, sem nenhuma especificação, aponta justamente para o fato de que não existe nenhuma ideia de "resgate cultural" subjacente à obra, senão uma referência às culturas endógenas como resíduos remanescentes da imensa destruição causada pela guerra. Neste sentido, ao lado dos compêndios e conhecimentos racionais que pouco serviam para a compreensão daquele caos, encontravam-se os conhecimentos "religiosa e oral- 
mente transmitidos" que tampouco ofereciam ensejo para a completa explanação de tudo o que agora ocorria.

Isso faz lembrar, a propósito, o caso do "poliandria" da mãe de Sabonete. Afinal, ela poderia ser chamada de "poliandra", caso as teorias antropológicas estivessem atentas à "verdade terrena”, ou caso essa fosse alguma prática cultural específica. No entanto, a poliandria daquela mulher era uma imposição da guerra, e não uma prática social (ou melhor, social na medida em que as pessoas assim se organizaram e relacionaram unicamente por conta da guerra). Assim sendo, não parece que seja muito pertinente acreditar que a crítica à racionalidade e à erudição ocidental seja central em Os sobreviventes da noite, mais do que uma busca incessante e estupefata por alguma compreensão diante da destruição total, do caos. A racionalidade ocidental não está vista aqui como uma opressora colonial, mas sim como uma ferramenta inútil para a análise do terror da situação da guerra. Essa voz narrativa estupefata, inclusive, parece ser habilmente versada nos "compêndios" que agora de muito pouco servem, como veremos adiante no caso de certas apropriações pontuais que faz de um repertório da cultura clássica.

Outrossim, é possível identificar certos trechos em que esse narrador deixa claro que os costumes e práticas da guerra estão distantes do mundo logicamente ordenado pelo pensamento racional, mas também distantes das práticas culturais anteriores à chegada da hecatombe da guerra. Como se pode ler (OSN, p. 33):

Mas a guerra, apesar dos relativos períodos de repouso, tornara-se já, no espírito de Severino, António, Penete, João, Francisco e outros, algo de orgânico. Ela circulava no corpo com a mesma naturalidade com que o sangue percorre as veias. E ela tinha que ser alimentada, nutrida. O ciclo orgânico obedecia a regras previamente determinadas, a horários escrupulosamente programados. $\mathrm{O}$ tempo, na esquisita roda da vida guerreira, não corria com a precisão milimétrica das urbanas máquinas de ponteiros precisos, e muito menos ao sabor rural. 
Aqui se percebe como a guerra assume uma dimensão além mesmo de práticas e costumes, mas sim fisiológica. Existiria certo "ciclo orgânico" definido previamente, com horários programados, o que se verificou no caso da hora da "suruma" e também em certa organização do espaço, que, embora esteja armada sobre a destruição, conseguia manter espaços definidos pela hierarquia da guerra. $\mathrm{O}$ tempo da guerra, no entanto, encontra-se igualmente distante tanto da cultura urbana ("máquinas de ponteiros precisos") quanto das possibilidades oferecidas pelas culturas abatidas pela guerra ("o sabor rural”, e aqui temos novamente a marca geográfica que, por metonímia, identifica um universo cultural endógeno). É nessa mesma brecha entre um universo e outro que se encontra o nosso narrador, que oscila entre um espaço cultural e outro tentando encontrar o entendimento que possibilitará a ele a narração desse momento sui generis que lhe parece tão caro e difícil de compreender. Ainda assim, em vários momentos o narrador enfatiza seus "pés africanos", quer dizer, estar distante tanto da cultura ocidental quanto das culturas pré-guerra não lhe impede de, ainda assim, perceber-se como inserido num contexto de dimensão continental, como se vê (OSN, p. 48):

Mas o que se passou na vila durante aqueles cinco dias não diferia tanto de outras ocupações armadas e violentas pela África e o restante mundo de ódio e desigualdades. As violações, o saque, as mortes, nas suas várias vertentes eram as mesmas.

Mais do que uma ótica continental africana, nesse trecho o narrador insere seu relato num comum "mundo de ódio e desigualdades", que incluiria o continente africano todo, para os quais as "violações, o saque, as mortes" seriam "as mesmas". Desse modo, conspira nas entrelinhas um sentimento solidário de identificação de como a guerra que ora lhe causa estupor se repetiria em "várias vertentes" e em outros lugares do mundo que se irmanariam pelo ódio e pela 
desigualdade. Essa identificação o afasta da cultura ocidental hegemônica ao mesmo tempo em que o impede de se aprofundar e aproximar demasiadamente daquelas culturas que no tempo presente daquela narrativa estão destruídas e dissolutas.

\subsection{Caos como ordem}

A forma como o narrador se apropria da cultura racional ocidental como ferramenta de análise para a situação que quer narrar, ora sendo útil, ora sendo inútil, fica evidente em alguns momentos específicos em que chega a utilizar mitos clássicos como instrumental metafórico ou analógico de compreensão do universo que descreve. Um deles é quando lança mão do mito de Cassandra, outro quando cita rapidamente o mito de Jacinto e, por fim, quando lança mão do mito do Caos, do qual se extrai certa estrutura permanente que será utilizada em todo o romance como signo final de composição.

Uma das características de Sabonete, de quem trataremos com vagar mais adiante, é contar histórias nas quais ninguém acreditava, por não saber "estabelecer a ponte entre o trágico, o macabro, o cómico e o jocoso" (OSN, p. 106). O discurso indecoroso de Sabonete causava incredulidade pois "nenhum mortal, por mais atavios que tivesse no corpo, é insensível ao horror" (OSN, p. 107). Ao tratar dessa característica de uma pessoa a quem o discurso nunca merece crédito, nosso narrador toma o mito de Cassandra (OSN, loc. cit.):

Todos os esforços de persuasão de Sabonete caíam por terra. Lembra o mito da Cassandra que as rurais mentes do acampamento não conheciam e nem estavam preocupados em conhecer, pois Cassandra, essa filha de Príamo a quem Apolo, na vã tentativa de seduzi-la, prometeu os dons da profecia e adivinhação, ao que ela, instruída, não cedeu aos desejos e a quem despeitado Apolo cuspiu na boca, privando-a do dom da persuasão, há muitas em mundos terceiros, umas em corpos de mulher e outras em de homem. 
O mito de Cassandra tem diversas fontes na épica e na tragédia grega: a própria Ilíada ou a Odisseia de Homero trazem referências a ele (Ilíada, XXIV, p. 697-706; Odisseia, XI, p. 405-434), assim como Eurípedes, em As troianas e Electra. No entanto, é em Agamemnon, de Ésquilo (TORRANO, 2012), que o ato do cuspe de Apolo aparece como castigo à recusa de Cassandra (PEREIRA, 2007, p. 76). Salta aos olhos, além da apropriação do mito clássico e a consequente aplicação analógica à situação de Sabonete, a marcação destacada do deslocamento do mito numa geografia cultural: "as rurais mentes" não tinham acesso nem tampouco queriam ter, e mais, haveria muitas Cassandras em "mundos terceiros". Ou seja, a apropriação do mito foi realizada com o cuidado de demarcar seu deslocamento até o "terceiro mundo", enfatizando, novamente, uma consciência geopolítica global ao lado da apropriação de um mito ocidental.

A segunda tomada da mitologia clássica ocorre quando cita certa personagem chamada Jacinta, localizada num engaste narrativo durante a história de Malaquias. Ao citar o nome da personagem, o narrador retoma a origem desse nome na mitologia clássica, como se vê (OSN, p. 92):

[...] mulher última do irmão [...] de nome Jacinta, feminino de Jacinto que a mitologia grega nos dá como um dos grandes amores de Apolo, metamorfoseando-se depois da morte na bela e vistosa flor que todos chamamos de Jacinto, desconhecendo ela, como é prática nestes mundos terceiros, a origem e significado do nome [...].

Novamente se percebe o esforço por retomar o dado clássico. Com efeito, o mito de Jacinto pode ser lido na chamada "mitologia grega”, mais precisamente na Ilíada de Homero (II, 595-600), mas também no repertório latino, nas Metamorfoses de Ovídio (10, 162 219). Salta aos olhos novamente o fato de o narrador tomar o cuidado 
de fazer o mito transitar e mostrar que conhece a origem de um nome que o próprio nominado desconhece, e de afirmar que isso seja prática comum num "terceiro mundo".

O mais importante apelo à mitologia clássica ocorre quando, no interior da guerra, a voz narrativa define o estado de destruição total como o Caos. Esse Caos grego que ele busca na cultura clássica (OSN, p. 86):

O sol caíra cansado e vermelho. As estrelas, irmãs menores do sol grande, assemelhando-se a milhares e milhares de pirilampos possuídos de um priapismo que não permitia o momentâneo desfalecimento da luz, tentavam desafiar a noite que acordava com a sua pujança tropical. A lua, cheia da sua luz amorosa, comandava o numeroso exército de estrelas feitas soldados com lanternas de luzes permanentes viradas à noite, esquecendo-se que ela, a noite, desde os imemoriais tempos em que os gregos grafaram os seus mitos teogónicos, é filha directa do Caos, matriz da existência. Porque no princípio dos princípios, tudo era Caos. Caos pela desorganização. Caos pela impossibilidade de dar lógica ao mundo. E só foi Eros, o amor, que trouxe a coesão, a força espiritual. Mas a noite, o caos, o indescritível, está sempre presente com o seu desordenado vigor.

Salta à vista certo embate entre luz e escuridão que se estabelece num jogo de imagens acumuladas em sequência. $O$ sol que se cansa e cai, as estrelas que desafiam a "pujança tropical" da noite, comparadas a pirilampos "possuídos de priapismo". Essas estrelas logo recebem o comando da lua, e são em seguida comparadas a um exército. Não será demais perceber como a belicosidade da guerra atinge metaforicamente o curso natural da chegada da noite na ótica da voz narrativa. Esse embate é sublimado em seguida em certa apropriação do mito clássico presente na Teogonia de Hesíodo, poema épico grego que descreve o surgimento do universo. A apropriação apela para o mito grego 
grafado em "tempos imemoriais", revelando uma ênfase sobre os deuses Caos e Eros, como pares opostos na formação do universo.

Uma rápida análise sobre os referidos deuses na Teogonia revela uma atenção dada pela voz narrativa a certas estruturas do épico grego que se replicam na estrutura de Os sobreviventes da noite. Segundo uma análise de Jaa Torrano sobre a ocorrência da palavra grega "Khaós", correspondente a Caos, esta é apresentada logo de início na Teogonia, numa primeira ocorrência, como resposta a uma pergunta dirigida às musas: "quem dentre os deuses nasceu primeiro?" (Teogonia, v. 115, cf. também TORRANO, 2012, p. 30). A relação entre esse deus e Eros é complexa e fundamentada por certa complementaridade. Segundo diz Torrano (2012, p. 32):

A simetria entre Caos e Eros como nomes de ação permite-nos pensar que descrevem as duas formas de procriação pelas quais se desdobram as genealogias divinas da Teogonia, Caos nomeando a procriação por cissiparidade, e Eros nomeando a procriação por união amorosa.

Logo em seguida na Teogonia, a segunda ocorrência de "Khaós" revela que, pelo processo de reprodução por cissiparidade, este teria gerado Êrebos (vernaculização do grego "Érebos", que designa as "trevas subterrâneas") e a Noite "negra”. Ambos os filhos do Caos, a Noite e Êrebos, unidos numa união amorosa mediada por Eros, geraram, por sua vez, o Éter e o Dia (Éter aqui designando o fulgor diurno e noturno do céu). Em relação a essa procriação das trevas que geram a luz, afirma novamente Torrano (2012, p. 33):

Os nomes femininos Hemére, traduzido "Dia”, e Nýx, traduzido "Noite", associados aos nomes masculinos Êrebos e Éter, compõem dois pares antitéticos, sendo o par tenebroso gerado por cissiparidade e o par luminoso gerado por união amorosa. Assim se explicita a natureza sombria de Caos e a sua confinidade e complementaridade com a natureza luminosa de Eros. 
Ora, em Os sobreviventes da noite nosso narrador afirma justamente que a noite "é filha directa do Caos". Ele chega a reconstituir, inclusive, um grupo de elementos tenebrosos, originários do Caos: "a noite, o caos, o indescritível, está sempre presente com o seu desordenado vigor" (destaque-se uma segunda ocorrência da palavra "caos" no romance, desta vez em caixa baixa: um caos derivado do Caos?). Na Teogonia, a Noite, filha de Caos, era a origem da Morte, do Escárnio, da Sorte negra ${ }^{10}$, no sentido pejorativo. Esses sinais negativos todos atribuídos no épico grego aos filhos da Noite decerto aqui também estão designando a noite que se compõe ao longo do romance. Noite que está, inclusive, posta no título e da qual restam sobreviventes. Evidentemente, a apropriação do mito grego aqui está em função do estupor causado pela situação da guerra diante do olhar desse narrador confuso entre a tentativa de narrar uma situação, por assim dizer, caótica, e a impossibilidade de fazê-lo por meios racionais, ainda que muitos aspectos do pensamento ocidental lhe sirvam de instrumental mais ou menos útil para descrevê-la.

Ainda assim, a oposição complementar que se estabelece no clássico grego entre a reprodução pela união amorosa própria de Eros e a reprodução por cissiparidade que é própria de Caos parece figurar também, de alguma forma, em Os sobreviventes da noite. Por diversos momentos a guerra é exibida como um espaço de esterilidade e impossibilidade de geração de novas vidas pelo conluio de duas pessoas. Essa esterilidade é causada pela ausência total de qualquer possibilidade de relação erótica, bem pesado o termo, ou pela ausência de amor. Conforme podemos ler (OSN, p. 58):

\footnotetext{
${ }^{10}$ Ipsis litteris, estes são os versos da Teogonia:

"Noite pariu hediondo Lote, Sorte negra

e Morte, pariu Sono e pariu a grei de Sonhos.

A seguir Escárnio e Miséria cheia de dor.

Com nenhum conúbio divina pariu-os Noite trevosa." (Teogonia, vv. 213 - 232, Hesíodo, 1995, tradução de Jaa Torrano).
} 
Porque o amor, esse, há muito tempo que não existia no dicionário dos homens e mulheres que se revezavam pelos intermináveis acampamentos das florestas e savanas. As mulheres e os homens agarravam-se, com condescendência ou não, a parceiros ocasionais e desaguavam as energias do cio de predadores, ruminantes e larvas, em leitos de areia, palha, troncos, cimento, ou em camas de administradores, funcionários subalternos, comerciantes, motoristas, e inocentes camponeses com que se cruzavam na devastação sem nome e sentido.

O fato de que nem sempre era necessário que houvesse algum tipo de vínculo consensual para a realização do sexo, ou mesmo do estabelecimento de relações que pudessem ser definidas com o mínimo de afeto, é descrita através de um processo estético que abusa de referências zoomorfocizantes: as pessoas "agarravam-se, com condescendência ou não", os parceiros eram ocasionais, e o ato do sexo era um "desaguar de energias do cio de predadores, ruminantes e larvas". O resultado dessa impossibilidade afetiva no contexto da guerra produz a infertilidade, e essa sentença é definida em dois momentos na fala do velho Malaquias (OSN, p. 65):

- [...] Mas a pressa com que os homens se acasalam e trocam de parceiros é tão grande que a foda deixa de ter gozo. Aqui não se ama. E quando não há amor não há filhos, há bastardos. Pelos acampamentos por onde passei vi poucos bebés. Não ouvi aquele choro de bebés que dão vida a uma povoação. Só oiço choro de adultos.

Essa infertilidade, perceba-se, é mais conceitual do que fisiológica. Quer dizer, pessoas eram geradas, mas não podiam ser consideradas nascituros ou "filhos". A história do próprio Sabonete, de que trataremos adiante com vagar, é exemplo disso. Filho da guerra, era considerado como nascido de "uma termiteira velha" (OSN, p. 22). À infertilidade conceitual soma-se uma infertilidade estatística: o 
velho Malaquias viu poucos bebês pelos acampamentos por que passara. $\mathrm{O}$ outro momento em que se define essa infertilidade pode ser visto no seguinte trecho (OSN, p. 113):

Tudo o que se movimentava e falava, em idade maior ou menor, não podia ser criança. No acampamento só existiam homens e mulheres. Todos fodiam e bebiam. Todos, ou quase todos, matavam. E poucos engravidavam, não por infertilidade genética, mas porque o coito, a foda, o espermatozoide, carregava em si o estigma da infertilidade dos que do rapto faziam o ofício da sobrevivência. A cópula, como dizia o Malaquias, só pode ser fértil quando feita com amor.

As pessoas geradas nos acampamentos da guerra, além de não serem considerados "filhos", tampouco eram consideradas "crianças". $\mathrm{O}$ que quer dizer que não havia qualquer código ético que os isentasse de "foder", "beber" e "matar". Novamente a esterilidade estatística vem à tona, quando o narrador revela que a gravidez era rara, causada pelo "estigma da infertilidade" do rapto como ofício de sobrevivência. Ora, essa infertilidade em seus diversos aspectos está relacionada intimamente com o Caos que atravessa toda a guerra, tornando-a incapaz de produzir vida com amor. Isso não pode ser dissociado da oposição entre Caos e Eros que nosso narrador colhe da mitologia clássica da Teogonia.

Até aqui temos visto como Os sobreviventes da noite se constrói sobre uma voz narrativa onisciente que, para desenvolver sua narrativa, se imbui de certo estupor diante de uma situação extrema, com a qual se sente muito pouco habilitado para lançar mão de quaisquer dados para produzir análises qualitativas. Por isso se debate constantemente com uma cultura erudita, racional e ocidental que constantemente se mostra inútil até certo ponto para a compreensão daquela situação, mas também não deixa de ser um instrumental relevante para a sua aproximação. Dessa cultura, de alguma forma, deriva um repertório clássico que define uma constante que atravessa a obra: a 
desordem da guerra é comparada metaforicamente com o mito teogônico do Caos, do qual deriva também um conceito de Noite, definida como espaço de miséria e tenebrosidade, que também tem seus ecos na mitologia clássica.

Se o Caos aqui pode ser definido como signo de uma "desordem" perene que atravessa quaisquer descrições e situações contidas no interior do romance, outro signo possível de ser analisado no interior da obra é o da sobrevivência. Já vimos que a vida é ausente e impossível de se renovar, e que tudo o que existe no interior da guerra está inevitavelmente marcado pela dissolução. Essas características, no entanto, estão ligadas muito mais a certas designações adjetivas de elementos constituintes impessoais ou abstratos: a configuração espacial do acampamento, como se encaram as pessoas que nascem durante a guerra (nunca filhos ou crianças, mas bastardos e prontos para matar), para ficar em alguns exemplos. Quando personagens humanas concretas são chamadas à baila pela fluidez de nosso narrador, o signo se converte e duplica em sobrevida, em tempo presente, e dissolução em tempo passado. Isso quer dizer que no tempo presente da narrativa as personagens sobrevivem ao caos tenebroso e noturno, e o passado, momento da vida concreta, está sempre marcado pela dissolução e ausência. Esses signos percorrerão uma curta galeria de sete ou oito personagens que assumem o primeiro plano da narrativa, que merece ser analisada com cuidado.

\subsection{A sobrevivência}

Em meio à massa humana informe que os aritméticos números não poderiam contar, um pequeno número de personagens merece uma atenção redobrada da parte de nosso narrador, que, em detalhe da visão ampla sobre o acampamento, destaca-os, aproximando-se deles, de suas vidas, de sua personalidade e de suas histórias pessoais. 
Aproximar-se dessas personagens significa em Os sobreviventes da noite acessar a longa história e o trajeto pessoal de cada qual. Muitas vezes esse acesso ocorre, via a fluidez do narrador, num voo livre e inesperado ao passado mais remoto de cada personagem, de modo que o leitor pode mesmo até se perder em algumas genealogias que se embaralham a malha narrativa.

Existe um núcleo específico de quatro jovens que ganha uma atenção insuperável na economia da obra. Trata-se de Severino, Penete, António Boca e José Sabonete. Esse pequeno núcleo tem um reconhecimento militar que garante a eles certa autonomia relativa. A forma como se relacionam, inclusive, replica certa hierarquia que abarca todo o acampamento e, por conseguinte, toda a guerra. Como podemos ver (OSN, p. 26-27):

Ao dizer isto, Severino pegou na sua arma e na catana a que tinha direito, deixando a outra nas mãos de Sabonete que se limitou a entregar as catanas a Penete e António que não tinham, por escassez, o direito de uso pessoal de armas de fogo. [...] Quando em assaltos, o trabalho dos dois limitava-se à pilhagem e ao carregamento de bens das aldeias saqueadas. Em caso de necessidade e gozo, e a mando de Severino, António e Sabonete eram encarregues de cortar membros e, não poucas vezes, de degolar os capturados. A estas tarefas, Boca e Sabonete não tinham como negar. Sabonete cumpria o seu trabalho com um sorriso despontando dos lábios carnudos, perguntando, amiúde, pelos pormenores ao Severino que, ao sabor da disposição de momento, mudava de ideais [...].

Severino era, portanto, um líder que desempenhava uma função crucial no meio dos outros três. Todos estavam subordinados a ele. Penete, um seu subordinado, era um garoto curioso e uma figura central na obra, pois atravessa toda ela carregando consigo uma gaiola sem pássaros. Essa gaiola é um resíduo anterior à guerra, que teria feito ainda criança, mas não para pegar pássaros (OSN, p. 100): 
Uma gaiola feita de arames, sem adornos, de bambu e outras esquisitices tropicais. Queria uma gaiola em que as aves se sentissem em casa e não numa prisão. Uma gaiola em que os passarinhos tivessem o à-vontade dos pombos: a liberdade de entrar e sair. Ao construí-la, com a natural impaciência da infância, não se preocupou com a beleza da porta, com a tranca, a tapa. Deixou uma simples abertura que trancava à noite com pedaços de bambu, ao jeito de troncos colocados e retirados dos currais pelos pastores.

No momento do assalto pelas tropas à vila, que acabou fazendo de Penete um cativo, este estava estudando numa igreja feita escola após a independência de Moçambique. Penete cursava o terceiro ano da escola, com uma dificuldade grandiosa. $\mathrm{O}$ caderno escolar, inclusive, acrescido do lápis e da borracha, teriam sido os "primeiros habitantes da gaiola" (OSN, p. 102). A vida de Penete, então, caminhava entre "dois mundos", o mundo da sua liberdade imaginativa, o mundo em que domesticava e tratava com seus pássaros, e o mundo da aprendizagem escolar, que, embora tivesse consciência de que este percurso era necessário para "ser gente", sentia nele uma dificuldade comparável a "labirintos e labirintos" (OSN, p. 103). Considerava o mundo escolar, no entanto, um caminho para "ser gente", e, para vencer os desafios, deveria "dedicar o grosso do tempo à profissão de domador", começando pelo lápis, depois o caderno, e assim consecutivamente (OSN, loc. cit.). Quando as tropas avançaram sobre a igreja feita escola, a condescendência do soldado que cuidou dos jovens futuros recrutas permitiu-lhe que levasse consigo sua gaiola (OSN, p. 48):

Entre os miúdos que ficaram enclausurados na igreja durante as primeiras horas da ocupação pontificava um de nove anos de idade. Pela aparência física não diferia das demais crianças. O que o realçava dos outros condiscípulos era a gaiola de pássaros, que nunca teve, servindo de carteira escolar. O homem armado, que se tornou responsável pela guarda dos futuros 
guerreiros, ficou tão deslumbrado com a gaiola feita carteira que chegou a perguntar ao moço:

- Para que é que a usas na escola?

- É para estar sempre perto de mim quando apanhar um pássaro, respondeu com o medo envolto nas palavras.

- Como é que te chamas?

- Penete.

- Para onde vais terás os pássaros que quiseres. Fica com ela. Mas, rasga os livros e os cadernos com os teus colegas. Onde vamos, não precisaremos desse material. Na nossa escola, o material é outro.

De posse da gaiola e feito soldado na guerra sem sentido aos nove anos, Penete, no entanto, nunca a utilizou para os pássaros, como assim teria sido anteriormente. A gaiola transforma-se, no contexto da guerra, num curioso espaço de preservação de memórias, imagens e pessoas. A gaiola se define como esse espaço através de um procedimento estético metafórico, sem nenhum tipo de mediação, em que o narrador afirma que Penete "guardava" as pessoas e as imagens no interior da gaiola, como se vê (OSN, p. 26):

Quando só, e em jeito de leitura, Penete passava os dedos pelos fios de arame da gaiola, libertando com os seus gestos imagens fantasiosas, corpos coloridos e desbotados, e vozes com histórias amontoadas no vazio da gaiola zombeteado por todos quantos o vissem na ligeireza do seu passo infantil com a gaiola presa na axila direita do corpo de menino de coro infantil das rústicas primárias escolas rurais do $\mathrm{ABC}$.

Muitas personagens passam pela gaiola, e muitas definições e descrições a que o narrador nos dá acesso ocorrem por conta de certa proximidade entre o foco narrativo e a forma como Penete percebia a presença dessas personagens ao colocá-las no interior da gaiola. Mas algumas vezes há em que o narrador propõe certa mediação, deixando claro alguma distância. Característica central da personagem, a gaiola 
anexada ao corpo do garoto atribui-lhe certo ar de ingenuidade que ocasiona por parte dos companheiros de guerra um "acarinhamento", pela resistente puerilidade manifesta na figura da gaiola, mas também por ser considerado "um menino da corte, o valido de Severino", ao mesmo tempo que era visto "como um simples objecto de decoração, uma voz sem voz, uma criança não criança” (OSN, p. 113); afinal, ninguém no acampamento era efetivamente considerado criança.

Penete alimenta certa relação estreita com outro menino do acampamento: António Boca. António Boca, um garoto mudo, pouco se lembra de sua origem, e o narrador parece compartilhar dessa deficiência reiterando o fato, trazendo, por mais de uma vez, a mesma história do trágico momento em que António vê o pai ser assassinado. Mário Covell era o nome do pai de António, e sabemos dele que era um exímio caçador admirado pela aldeia totalmente rural em que viviam ("as pessoas viviam da enxada, da caça, e da pastorícia; sabia que nessa aldeia não havia escola nem hospital"). A admiração, no entanto, se converte em ódio, num processo misterioso, que só poderemos entender se colocado em relação a diversas outras histórias que se repetem em formas semelhantes ao longo da obra. Veja-se (OSN, p. 17-18):

O que ficou na mente de Boca foi o grito lancinante do pai, Mário Covell, homem de meia estatura, conhecido na aldeia como um astuto e manhoso caçador nas acertadas ratoeiras que fazia aos animais que à aldeia trazia ante a satisfação de todos, todos os que depois o vituperaram em silêncio no dia em que outros animais lhe pregaram uma ratoeira a que não soube escapar e o arrastaram, tal como ele fazia às gazelas e impalas, até à aldeia denunciada sob tortura. Amarrado nos pés e atado nas mãos, Covell estava na posição de um Kudu ferido [...]. E ao ver o filho mais novo, teve energia o suficiente para lançar um grito de desespero: - Foge, António!...

Isso é tudo o que podemos acessar da história de Boca. Ficamos sem saber exatamente o que é que converte a admiração da aldeia 
por Mário Covell em ódio e vituperação no momento de sua morte. Parece existir certa ressonância entre esse episódio e diversos outros que se espalham ao longo da obra que tratam daquelas pessoas que passaram a ser consideradas "reacionárias" e "contrarrevolucionárias" após a independência. No entanto, isso não está claro. Existe certo silêncio sobre a história de Boca por parte do narrador, que, de alguma forma, replica o mesmo silêncio que existe na memória do próprio Boca. Sua memória mais longínqua é exatamente o momento em que o pai é baleado. De nada mais pode se lembrar (OSN, p. 112):

O [mundo] dele tinha, como princípio, o dia em que o pai, aprisionado como um kudo, fora morto na hora em que lançara o desesperado grito à sua fuga. Era o momento que sempre lhe vinha à mente. Para trás não via nada, não existia nada. $\mathrm{O}$ mundo que vivia começava no exacto momento em que o pai fora baleado e a aldeia queimada.

Boca parece, portanto, uma das personagens mais enigmáticas de Os sobreviventes da noite. Sobretudo porque apresenta certo comportamento indecifrável alimentado pela mudez, que reduz suas possibilidades comunicativas. Quando em exercício na guerra, apresentava um comportamento apático incomum e intrigante: nunca parecia ter dimensão exata da barbárie das atitudes que tomava. Essa curiosidade enigmática é apresentada pelo narrador através da ótica de Severino, que, ao observar o subordinado de guerra, ficava sem compreendê-lo. Severino empreendia esforços para decifrar o enigma, mas nunca lograva êxito, restando disso certo cuidado em relação ao garoto, manifestado por afagos (OSN, p. 28-29):

Algo de estranho apossava-se dele ao assistir ao António a degolar um velho, a estuprar uma moça, ou a amputar um braço. Perguntava-se sempre: que sentiria Boca ao tomar em mãos orelhas ensanguentadas ou olhos fora das órbitas? [...] Mas 
Boca era um tronco em movimento. Da sua boca não saía uma palavra, um gesto que levasse Severino a penetrar no solitário e codificado mundo do mudo [...]. Mas, no fundo, e para seu contento, Severino sabia que tinha em António alguém a quem pudesse aliviar a saturada bílis sem o receio da traição e intriga. Daí o constante gesto de afagar o desalinhado cabelo de Boca.

A apatia do garoto esmorece, no entanto, em contato justamente com Penete. Com este formava um par complementar em que as limitações de um eram supridas pelo excesso do outro, e um vínculo comunicativo intenso se estabelece. Esse vínculo comunicativo é imbuído de certa ingenuidade que desafia aquela ausência de infância que está determinada desde o princípio no interior do romance. De modo que um ao lado do outro reestabelecem a tendência à infância desafiando a ordem comum caótica que estava estabelecida no acampamento. Isso é descrito de uma forma específica pela voz narrativa em que a complementaridade de António Boca e Penete além, de estabelecer comunicação, está metaforizada como um “casamento", como se vê (OSN, p. 26):

Só os dois, Penete e António, é que se davam ao luxo de se comunicarem com laivos da pureza infantil ainda grudada nos tísicos corpos de guerreiros do desconhecido.

Em Penete era a voz, a fala. No Boca, o movimento, o sorriso, a lágrima, a ansiedade, o medo. Nos dois, o gesto e a fala, o cruzamento, o casamento, a união de uma comunicação profundamente anquilosada em seculares raízes de que não há memória.

A complementaridade parece contribuir reciprocamente a ambos, pois, além de estabelecer o vínculo comunicativo com Boca, que com ninguém mais o faz, também permite que a Penete lhe seja dado um companheiro das viagens solitárias pela gaiola, como podemos ver (OSN, p. 111-112): 
Na verdade, quando Penete se ilhava com a gaiola sem pássaros não estava só. Boca acompanhava-o a certa distância. Via-o tirar os pequenos troncos de bambu da porta, e arrumá-los, com certa solenidade, no interior da gaiola. A sua presença não incomodava Penete no silencioso diálogo com os seus personagens. Boca era mais uma sombra em seu redor. Habituara-se tanto a ela que em falta ficava preocupado.

Outra personagem desse pequeno núcleo militar há que recebe uma atenção maior por parte da voz narrativa: José Sabonete. Sabonete tem uma história complexa: é nascido da guerra, e, portanto, sequer sabe exatamente quem era o pai ou a mãe. A mãe, pelo que o narrador pode supor baseado na fala do velho Matias, teria servido de "amásia" a meia dúzia de guerreiros. Seu anonimato era debitário, sobretudo, ao fato de os guerreiros não a considerarem nem uma mulher, nem uma concubina, "mas uma simples e detestável depositária do sémen acumulado nos longos dias de fome, angústia, ódio, terror, e alguma pitada de alegria e prazer" (OSN, p. 19-20). A mãe morta no parto, os guerreiros vagaram sem rumo até encontrarem algum acampamento com mulheres para cuidar do garoto. Seu excêntrico nome foi escolhido justamente por conta da recusa de todos os guerreiros a atribuir o seu próprio sobrenome ao garoto indesejado. A imagem que narra o fato é carregada de uma simbologia metalinguística e, ao mesmo tempo, escatológica (OSN, p. 21):

E foi nesse manejo de imagens que as palavras sabão e sabonete se soltaram das línguas e se digladiaram a céu aberto, até à extenuada vitória do sabonete, por ser um produto sonhado e nunca utilizado. A vitória do sabonete deveu-se também, ainda que ninguém fizesse menção, à repugnante imagem que lhes passava pela mente do bebé, coberto pela cor leitosa do esperma que exalava o nauseabundo cheiro de peixes podres. Assim ficou baptizado Sabonete. 
Crescido como filho da guerra, ser recrutado para o grupo de Severino representou uma interrupção em sua vida ironicamente considerada "pacata, sossegada, no desassossego dos dias de tiros e bombardeamentos aos acampamentos" (OSN, p. 22). Com efeito, Severino mantinha uma relação de brutalidade com o garoto, dirigindo-se a ele sempre em "tom seco, áspero, agreste" (OSN, loc. cit.). Essa relação, censurada pelo próprio Penete (OSN, p. 25), talvez se devesse ao fato de Sabonete ser o lugar-tenente de Severino no núcleo militar. Severino alimentava certa confiança em Sabonete, justamente por esse ter "um imaginário que não se encaixava nos lógicos moldes estruturados pelos demais" (OSN, p. 29). Isso fazia com que ninguém desse crédito às suas histórias, de modo que Severino poderia confiar qualquer informação a ele, pois ninguém levaria a sério. Essa mente fantasiosa é definida pela voz narrativa como uma persistência pueril, como vemos (OSN, loc. cit.):

E esse ar distante e infantil, muito a jeito dos pintores de traços leves e macios em cenas de invulgar brutalidade, agradava a Severino, pois sabia que, da mais macabra história que saísse da boca do seu lugar-tenente, ninguém o levaria a sério.

Assim como António Boca, José Sabonete também causava espécie em Severino. Assim como a apatia incomunicável de Boca, Sabonete também desempenhava as ordens mórbidas da rotina da guerra com uma sensação inesperada: ninguém sabia se sentia horror ou alegria, pois se apresentava sempre com um terrível sorriso macabro nos lábios. Mesmo quando era agredido por Severino, não se sabia ao certo como se articulava com a dor; o sorriso era sempre presente. Temos acesso a isso por duas vias: quando o narrador se aproxima do estranhamento causado a Severino, e pela gaiola de Penete: "estranhava-lhe o facto de Sabonete sorrir da mesma forma quando decapitava um cativo sem nome, ou em presença de uma galinha assada em semana de fome" (OSN, p. 108). 
Severino recebe por parte da voz narrativa um tratamento diferenciado. A maior parte das informações a respeito de nossas personagens é trazida para o romance através de retrocessos ao passado de cada um, descrições do tempo presente, ou a narração de situações costumeiras. No entanto, são pouquíssimos os retrocessos ao passado que envolvem Severino, assim como poucas são as descrições que lhe adjetivam a personalidade. Severino é uma personagem muito mais composta em tempo presente, e as características de sua personalidade estão dadas, na maioria das vezes, em função da forma como costuma se relacionar com seus pares de batalha. As poucas ações do tempo presente da narrativa (assunto de que trataremos adiante) estão, em sua maioria, preenchidas pela assídua participação de Severino. De todo modo, alguns trechos descritivos são bastante significativos (OSN, p. 27-28):

Perante tais actos, Severino já não se emocionava como antigamente, altura em que obrigava os recém-recrutados a cortarem os amedrontados testículos dos homens indefesos, e os seios em flor de virgens adolescentes em emboscadas semelhantes a um ataque de macacos a machambas desguarnecidas, em sinal de vingança ao que lhe fizeram no baptismo de guerra quando o comandante Roque, visivelmente embriagado, o obrigou a empalar uma jovem de treze anos pela vagina adentro. Daí em diante, as imagens de carnificina não o perturbavam [...].

Diferentemente do que pudemos depreender do desenho das demais personagens, Severino obtém prazer nos atos crudelíssimos praticados nas rotinas dos saques e ataques às aldeias. Era diferente da apatia de Boca ou do sorriso enigmático de Sabonete. O prazer próprio era acrescido toda vez em que ordenava aos novatos que fizessem os tais atos, e isso, de uma forma bem clara, está posto como um círculo vicioso no qual Severino, e por conseguinte os demais, estavam 
enredados. O prazer na carnificina de Severino era uma forma de vingança à empalação a que fora obrigado pelo comandante Roque embriagado. Esse prazer na carnificina era depurado por Severino ordenando aos outros que fizessem igualmente aquilo a que fora obrigado fazer. Como se pode ver ainda (OSN, p. 59):

Dizia para si, Penete, que Severino gostava do fogo. E realmente gostava. Gostava de ouvir o grito dos deserdados. Gostava de ver a tropelia dos sem nada no encalço de qualquer coisa da sua sobrevivência. Gostava de ouvir, nas diabruras dos angustiados, as palavras mais escabrosas que um ser humano pode proferir.

No entanto, caímos in media res na história de Severino. Podemos ver nas descrições que se marcam dois tempos: um anterior, em que o gosto pela carnificina era persistente, e outro posterior, em que o desejo está arrefecido. Isso ocorre por conta de algo que se sucede num passado iterativo, não no presente da ação, nem no passado remoto dessa personagem. Trata-se de uma relação com Rosa. Curiosamente, das vezes em que essa relação salta para a malha narrativa, certo ar de pudor e vergonha prevalece: Severino tentando esconder dos demais o que teria acontecido durante as noites que passava com a moça Rosa (OSN, p. 60). A crueldade de Severino nos campos de batalha teria sido interpretada por Rosa como relacionada com a vida sexual do garoto, o que não deixa de ser surpreendente no contexto do acampamento, em que nem crianças eram vistas como tais (OSN, p. 57):

Ao seu grupo juntou-se mais tarde o já experimentado jovem guerreiro Severino, acompanhado sempre pelo velho Matias que desaparecia e reaparecia em momentos inesperados. Severino, centímetros acima da sua altura, contava ao tempo dezasseis ou dezassete anos. Era já um combatente respeitado pela ferocidade com que executava os seus inimigos. 
Dizia-se que era a suruma e outras drogas que todos consumiam que o moviam com tal desumanidade. Tal argumento não se encaixava na mente da Rosa, pois, no fundo do seu coração, manteve a certeza de que Severino padecia dos defeitos da virgindade prolongada.

Justamente pelo ato sexual de Severino e Rosa ser um ato obscuro e secreto é que se pode atribuir a ele um aspecto de subversão. Nosso eloquente narrador não trata disso, no entanto, e ficamos a nos questionar qual era o exato motivo que constrangeria Severino a ocultar sua relação. Ora, a resposta mais óbvia que daí se depreende é que aquela esterilidade que marcava o acampamento e, por extensão, toda a guerra, talvez fosse muito menos metafísica, como queria nosso narrador, do que coercitiva, no sentido de que qualquer relação mais erótica que fisiológica poderia representar uma ameaça à manutenção da guerra. Da conversa entre os velhos Matias e Malaquias, depreende-se uma análise dessa situação, em que Malaquias defende uma opinião terrivelmente pessimista em relação ao jovem Severino (OSN, p. 87):

- Severino mudou, Malaquias. A cabeça do miúdo está dividida entre a cama e as balas.

- Nunca vai sair da carne. Ele cresceu a ver sangue... É igual a muitos outros. $\mathrm{Tu}$ achas que podes repor o mundo que eles perderam ou nunca tiveram. É impossível. Aqueles que vislumbraram, ainda que esporadicamente, o mundo que sonharam ter, o mato cortou-lhes tudo. Deram-lhe armas e não sonhos, Matias. E as armas não sonham. As armas criam necessidades. $\mathrm{O}$ cair de uma cápsula puxa outra cápsula.

Ao percebermos isso, é possível pensarmos como aquelas características tão enfatizadas em António Boca, Penete e José Sabonete, a saber, o mutismo apático de um, a gaiola esvaziada de outro e o nefelibatismo do terceiro, sempre carregaram ares de infância em todas as descrições que tiveram. Por isso, não é raro perceber que essas 
características eram ridicularizadas pelo convívio no acampamento. $\mathrm{Na}$ verdade, a persistência dessas características pueris representava um contrassenso aos momentos em que o narrador afirmara que, no acampamento, ninguém era considerado criança. Ora, não ser considerado criança não significa aqui que esses indivíduos não possam carregar consigo certas características que revelem alguma infância estropiada nas curvas de suas personalidades. Essa infância resistente nos garotos, somada ao amor resistente de Severino e Rosa, representa pequenos furos ao bloqueio desumano que a guerra e a vida no acampamento impõem a esses sujeitos. Esses furos de resistência, somados a certas configurações narrativas na composição do quadro geral da guerra, e também a certa estrutura narrativa no tratamento do tempo, colocarão essa obra numa posição muito peculiar se pensarmos nas relações entre a estética e o contexto histórico a que essa obra, de alguma forma, faz referência. Comecemos pelo tempo.

\subsection{Camadas de temporalidades}

Desde o início temos tratado da configuração de uma voz narrativa central que, absolutamente onisciente, transita com extrema liberdade entre várias estâncias do romance: penetra a mente das personagens, as memórias de cada um, situações ocultas para todos, como o caso erótico de Severino. O resultado disso é que o romance não apresenta nenhuma solidez no andamento dos topos invocados: a fluidez narrativa é tão grande que certa confusão se gera para a compreensão de qual personagem está exatamente presente em certo instante da narrativa. A liberdade dessa fluidez, no entanto, esbarra numa limitação percebida desde o início: não existe a menor possibilidade de que a narrativa avance em sua dinâmica sem que cada história pessoal das personagens seja devidamente explicitada. Essa limitação é construída através de numerosos engastes narrativos que interceptam 
o tempo presente da narrativa e levam o narrador num voo livre em direção a diversos planos de passado das personagens ou do acampamento. Acompanhemos um caso bastante exemplar (OSN, p. 16-17):

- Não estás com fome?

- Não.

- Mas eu tenho.

- Faz como aquele gajo.

Penete olhou para o lado onde, agachado, se encontrava António. Melhor, António Boca. António de nome e Boca de alcunha, de boca, no sentido físico do termo, nada de anormal tinha [...]. Havia três anos que fora raptado de uma aldeia [...].

Neste excerto podemos perceber um tempo presente, em que Severino dialoga com Penete. Só o fato de Penete mirar Boca faz com que o narrador se desloque imediatamente daquele tempo presente $\mathrm{e}$ se dirija em direção à trajetória pessoal do garoto. Esse engaste é interrompido quando a narrativa retorna ao tempo presente, mas a fluidez desta é tão grande que o tempo presente não se solidifica, qualquer pretexto provoca um novo descolamento, e vamos novamente em direção a passados e passados, de personagens ou de acampamento.

Existem ao menos dois tipos de engastes narrativos na malha textual da narrativa. O primeiro e mais facilmente verificável é o tipo de engaste que se dirige a passados remotos, que trata da história pessoal das personagens, na maioria das vezes remontando como foi a trajetória que os levou para a guerra, ou também de fatos concretos ocorridos durante a guerra. Esses engastes estão sempre marcados pelo uso do verbo num pretérito perfeito real. Costumam configurar duas temporalidades de passado, uma pré-guerra e outra de fatos concretos ocorridos durante a guerra, como é o caso das histórias contadas por Sabonete (perceba-se: as histórias de Sabonete estão diante da polêmica de terem ocorrido ou não. No entanto, independentemente disso, consistem numa micronarrativa constituída no pretérito perfeito real, num passado concreto ocorrido durante a guerra). Este 
tipo de engaste, por exemplo, é verificável no capítulo 2: todo esse capítulo está construído na história pessoal de Rosa, e nenhuma construção narrativa em tempo presente ocorre; ele todo é simplesmente a história.

A outra possibilidade de engaste é aquela que se descola do presente, mas não se constitui num passado concreto, remoto ou não. É o tipo de engaste que se encaminha para a narração da rotina dos acampamentos de forma iterativa. As ações que se constituem sobre esse tipo de engaste podem ser percebidas como atitudes do cotidiano, que podem ou não acontecer no presente, e que aconteceram no tempo passado. Marcado textualmente pela predominância de verbos no pretérito imperfeito real ou atemporal, esse tipo de engaste é o mais difícil de ser percebido como tal, pois, na maioria das vezes, não está construído em contraste com um tempo presente da narrativa, como ocorre com o engaste de pretérito perfeito. Neste tipo de engaste, as relações temporais de anterioridade ou posterioridade da guerra não costumam estar claras, e, a partir dele, outros engastes em pretérito perfeito ocorrem. Vejamos alguns exemplos (OSN, p. 100):

Era sempre ao entardecer que Penete abria a gaiola sem pássaros. Uma gaiola feita de arame.

A partir desse trecho não podemos concluir que Penete teria aberto a gaiola no tempo presente da narrativa, como um fato que estava se constituindo durante a narração, nem tampouco que isso fosse um engaste que interrompesse o tempo presente da narrativa e partisse em busca de uma explicação do passado do garoto, ou da narração de um episódio em que ele teria aberto a gaiola num momento específico. O que podemos concluir é que aos entardeceres é que Penete tinha o hábito de tratar da gaiola. $\mathrm{O}$ contraste entre o engaste de pretérito perfeito real e o pretérito imperfeito iterativo pode ser visto em momentos como o seguinte (OSN, p. 108 -109): 
Esperava de Severino tudo que lhe ocorresse na alma, como no dia em que mandou cegar e empalar uma virgem pela vagina adentro ante o choro e a súplica de Penete, e os grunhidos de porco armadilhado do Boca. A cena não teve tanto mistério para o acto que Severino mandou executar.

Acabavam de saquear uma pequena povoação de dez ou quinze palhotas ligeiramente afastadas umas das outras por cinquenta ou cem metros [...].

Nesse trecho, em que se narra o difícil trato que Severino costumava alimentar em relação aos seus pares num passado iterativo, o passado concreto se constrói a partir da necessidade de narrar um momento específico em que a crueldade de Severino tivesse sido relevante. Desse modo, duas camadas de tempo pretérito alternam-se na narrativa, construindo a imagem de como era o acampamento, como se constituíam as relações entre as pessoas, como eram as práticas de guerra, num pretérito imperfeito iterativo, e a necessidade de considerar quem eram os atores daquela guerra, de onde vieram, por que estavam ali, constituindo um pretérito perfeito real e concreto.

Esses dois tempos pretéritos concorrem na economia da obra com um presente da narrativa que, de tão pequeno e mínimo, acaba sendo irrelevante durante quase toda a obra. Na maioria das vezes é composto por diálogos em que se faz referência ao fato de que naquela noite a chegar, o comandante Roque se faria presente, e haveria uma festa. Nesse tempo, em que seria provável que se depreendesse algum enredo, muito pouca coisa acontece. Ora, essa configuração temporal da obra acompanha a rotina do acampamento, como podemos ver (OSN, p. 61):

A tarde, como em outras dos tempos de acalmia, era passada sem sobressaltos. Fora a punição dos que não resistiram à espera do momento do consumo da suruma e outras drogas, a tarde era acompanhada até o ocaso com conversas banais como a que Penete trocava com Sabonete. 
Ou seja, toda aquela carnificina da guerra que passamos a conhecer, todas as histórias das personagens, todas as rotinas de saques e invasões, tudo está interrompido pelo estado de acalmia a que agora o acampamento passa. De modo que muita pouca coisa acontece em tempo presente, praticamente nada. $\mathrm{O}$ tom de quase todo o romance é que, não tendo nada para narrar, a voz narrativa destaca-se do presente e dirige-se com vigor para o passado de cada personagem, invocando todas as informações, ações e situações que forem precisas para que passemos a conhecê-las e compreender as razões pelas quais agora estão na guerra.

A letargia que perpassa por todo o tempo presente, justificada pela acalmia da guerra, é preenchida pela espera do comandante Roque, que chegaria à noite. Dentro dessa espera, alguns episódios se sucedem, como o caso do fraco do dia. Tratava-se de punir aquele que não resistisse à espera pela hora da alimentação ou do uso da suruma, no fim do dia (OSN, p. 33-37). Diante da torturante espera, aquele que fraquejasse era punido publicamente, física e moralmente. Todos esperavam ansiosamente para saber quem seria a pessoa punida. Nesse marasmo angustiante por que passava todo o acampamento, a natureza é sempre descrita como um universo absolutamente alheio a tudo o que ocorria em âmbito humano (OSN, p. 33, 54, por exemplo ${ }^{11}$ ).

O último capítulo, no entanto, é o único em que tendência apresentada em todo o romance, de estar muito mais inflado nos dois planos do pretérito que no tempo presente, entra em decadência. Nesse

\footnotetext{
11 Alguns casos pontuais, no entanto, representam tendência contrária à definição. Quando Severino mandou que os garotos cortassem o seio de uma adolescente encontrada viva numa aldeia saqueada, a natureza parece seguir o terror do momento (OSN, p. 109): "A um olhar atento, notava-se, em total contradição com os naturais hábitos, que os estorninhos se aconchegavam uns aos outros para além dos limites permitidos à conservação da espécie, denotando mais medo aos homens de armas que o possível perecimento das penas. De cães e latidos e ganidos, nem vivalma. O silêncio imperava na tarde que descia para o ocaso. A miúda estava tensa. Os estorninhos calados. As árvores imóveis".
} 
capítulo pode-se encontrar apenas dois ou três engastes que se afastam ligeiramente do tempo presente. No mais, é a narrativa em tempo presente da chegada da comitiva do comandante Roque ao acampamento totalmente provido de víveres e de prisioneiros. $\mathrm{O}$ dia seguinte seria a ocasião dos assassinatos dos prisioneiros que não seriam úteis ao acampamento, e é nesta ocasião que um conflito se estabelece: visando atacar Severino, o comandante Roque faria com que Penete pegasse em armas para assassinar um prisioneiro sexagenário. Avisado disso por Maxanissa, uma personagem que só no último instante surge, Severino foge com sua malta sem rumo, para evitar que Penete pegasse em armas, ou mesmo de ser desafiado pelo comandante. Ironicamente, Penete esquece a gaiola no acampamento. Uma pequena ação mínima que se estabelece no último segundo do romance.

Para esboçarmos uma forma analítica de compreendermos os planos narrativos de temporalidade em Os sobreviventes da noite, obteríamos a seguinte tabela:

Tabela 1 - Planos temporais de narração em Os sobreviventes da noite

\begin{tabular}{|c|c|c|}
\hline Plano temporal & Marca textual & Marca estética \\
\hline $\begin{array}{l}\text { Presente da } \\
\text { narrativa }\end{array}$ & $\begin{array}{l}\text { Momento atual da } \\
\text { narração, verbos no } \\
\text { pretérito perfeito }\end{array}$ & $\begin{array}{l}\text { Na maioria das vezes, diálogos. Curta } \\
\text { ação no último capítulo }\end{array}$ \\
\hline Passado concreto & $\begin{array}{l}\text { Verbos no pretérito } \\
\text { perfeito real }\end{array}$ & $\begin{array}{l}\text { Engastes narrativos de episódios pré- } \\
\text {-guerra (histórias pessoais de como } \\
\text { chegaram àquele presente), engastes } \\
\text { narrativos de episódios ocorridos } \\
\text { durante a guerra (micronarrativas de } \\
\text { situações ocorridas a qualquer momen- } \\
\text { to, menos no presente) }\end{array}$ \\
\hline Passado iterativo & $\begin{array}{l}\text { Verbos no pretérito } \\
\text { imperfeito real ou } \\
\text { atemporal }\end{array}$ & $\begin{array}{l}\text { Engastes narrativos em que a tempora- } \\
\text { lidade se dilui na narração de rotinas e } \\
\text { hábitos do cotidiano do acampamento. } \\
\text { Mais facilmente verificáveis se tomados } \\
\text { em contraste com o passado concreto }\end{array}$ \\
\hline
\end{tabular}


Ora, ainda que uma ação seja verificável em tempo presente durante todo o romance, a forma como ela está ofuscada pela grandiosa massa textual que preenche os outros dois planos temporais faz com que esse plano temporal presente se minimize ao ponto de quase perder a significância, caso não fosse salvo pelo prenúncio do acontecimento que se sucede no último capítulo. Ou seja, é como se o tempo presente da narrativa se constituísse em um fundo, um segundo plano latente, que está quase velado em todo o romance, menos importante enquanto nosso narrador se ocupa viciosamente de nos contar as histórias de cada personagem, a rotina de cada ato, cada minúcia do cotidiano naquele acampamento. Qualquer sinal de avanço no motor narrativo em tempo presente é logo embreado por uma nova interrupção que nos leva diretamente ao passado, como se essa narrativa em tempo presente fosse impossível caso aqueles pormenores não fossem devidamente explicitados.

Assim sendo, é como se essa galeria de personagens não adquirisse valor em tempo presente caso suas histórias e trajetórias não estivessem absolutamente trazidas para o presente do romance nessa dimensão passadiça composta por esses dois tipos de planos pretéritos, performatizados esteticamente como engastes narrativos. Trata-se um presente narrativo que não tem valor em si mesmo caso não esteja cronicamente dimensionado em relação a diversas camadas de passado. A essa forma de presente tartamudo, constrangido pelas dimensões passadiças de cada aspecto e personagem, poderíamos chamar de presente dependente, que, impossibilitado de avançar, carece constantemente de uma embreagem de passado explicitador. A recorrência desse presente dependente na constituição da narrativa é tamanha que o plano do presente ele-mesmo torna-se praticamente irrelevante, caso não fosse uma mínima ação.

As configurações estéticas em Os sobreviventes da noite estão sempre relacionadas com correlatos de conteúdo narrado, como 
vimos no caso da letargia do acampamento que se transfere para a narrativa transformando o presente numa espera angustiante em que pouca coisa acontece, ou ainda quando, lançando mão do mito do Caos grego, o narrador compõe uma voz de encruzilhada, narrando o caos de uma forma igualmente caótica e absolutamente fluida. Desse modo, é possível questionar o dado do presente dependente, de modo a compreender em quais relações e conexões esse dado pode se tornar significativo. Quer dizer, que ganho existe nessa configuração do presente dependente na economia da obra? O que motiva essa dependência narrativa que atrasa a ação em tempo presente da narrativa a ponto de quase nada acontecer em toda a obra?

Pensar nas configurações estéticas de Os sobreviventes da noite não pode, de forma alguma, estar em prejuízo da intensa referencialidade a que esse romance se propõe. Ou seja, não podemos nos esquecer de que toda essa complexa configuração estética está tratando de uma guerra ocorrida em Moçambique, e de que estamos a assistir a rotina de guerreiros recrutados compulsoriamente para a batalha através de saques e ataques totalmente avassaladores a aldeias e cidades ao longo do país. De forma sutil, nenhum nome é trazido para dentro do romance, nenhum dado histórico concreto é narrado, nenhum dos "lados" dessa guerra é nomeado (nem RENAMO, nem FRELIMO). O enfoque parece incidir justamente noutro lugar, diferente das altas discussões sobre alinhamentos políticos e conflitos internacionais, mas parece estar sobre a vida de cada um dos indivíduos que estão mencionados no texto.

Por isso a palavra "guerra" em toda a narrativa traz consigo um epíteto, que se metamorfoseia: é sempre chamada de "sem sentido", "sem razão", "sem lógica”. A discussão da guerra em si é muito pouco proveitosa para essa voz narrativa, pois a ela interessa muito mais a vida das personagens, suas histórias, o vasculhar entre as ideias e mentalidades de cada um do que os motivos dessa guerra de uma forma 
mais ampla. Os detalhes individuais interessam mais ao narrador do que mesmo o tempo presente da narrativa. Isso se pode evidenciar pelo intenso caráter involuntário da permanência de qualquer personagem na guerra. Até mesmo o comandante Roque, figura da mais alta patente presente na narrativa, não concebe exatamente por que é que precisavam matar "comunistas", pelo que se vê neste diálogo entre Matias e Malaquias (OSN, p. 86):

- E quando perguntei ao comandante Roque o que é que ele queria dizer com a palavra, o homem andou às voltas.

- O que é que ele disse?

- Que não conhecia o significado da palavra comunista. Os seus chefes ensinaram-lhe a chamar os inimigos de comunistas. E, quando lhes perguntou o significado da palavra, também disseram que não sabiam e que também os ensinaram a pronunciar tal palavra. Por isso, Malaquias, disseram-me, carrega na boca a palavra comunista. Quando queimares uma palhota ela é comunista. Quando abateres um homem, ele é comunista. Quando violares uma mulher, ela é comunista. Se destruíres uma árvore ou uma ponte, elas são dos comunistas. Tudo o que não estiver na nossa margem é comunista. Casas, pontes, estradas, homens, mulheres e crianças que estiverem na outra margem são comunistas. Foi isso que me ensinaram, Matias.

Ora, se o comandante Roque sequer sabia o que era comunista, o que o motivava a ser o elemento propulsor da matança na hierarquia do acampamento? Nosso narrador não está interessado em discutir o que era "comunista", nem tampouco o que estava em ambas as margens da guerra, mas tem tempo para narrar o que era exatamente que vinha à mente do comandante quando pegava em armas. Pelo que se pode ver (OSN, p. 127):

Ele não sabia o que era uma nação. A sua pátria era sua tribo [sic]. O seu Deus eram os seus espíritos ancestrais. Arrancaram-no, 
como aos outros, da terra-mãe e deram-lhe uma arma. E fazia bom uso dela, porque sabia que, ao voltar à terra-mãe, seria recebido como herói, e gozaria da mesma respeitabilidade por parte da população tal como a que as linhagens reais desfrutavam. Sonhava ter o mesmo estatuto que o régulo da sua terra. Queria receber as oferendas que assiduamente os camponeses faziam chegar à palhota da grande realeza. [...] Daí o afinco, a tenacidade, com que se entregava à tarefa da guerra.

Se o próprio comandante não sabia o que era o motivo da guerra, as demais personagens tampouco saberiam. Vejam-se os seguintes excertos, donde se depreende que nem Severino nem o Matias sabiam as razões e as causas das armas (OSN, p. 60):

Boca, na mudez do seu desencanto, era da opinião que Severino estava falando com as estrelas. A violência com que tratava os inimigos comunistas de cuja substância não tinha noção, o rude trato que dava aos prisioneiros nos ataques sem glória [...].

E ainda, Matias, quando reflete a respeito da vida interrompida quando fora raptado pela guerra (OSN, p. 65):

- E eu com a machamba preparada.

- Tens que esquecer.

- Esquecer uma ova... Ainda se soubesse como é que esta porcaria começou, talvez entendesse quando é que isto vai terminar. Mas um gajo só está aqui para matar. Um dia destes ainda me aparece um filho meu com uma arma apontada aos meus colhões.

Nesse processo de total alheamento das personagens em relação às causas da guerra, a voz narrativa deixa claro em muitos momentos o distanciamento da maioria das personagens dos processos políticos anteriores à guerra. De modo que, mesmo na guerra, encontram-se cindidos entre "as margens", ambas incompreensíveis de todo 
modo. Afinal, se agora não entendem os "comunistas" enquanto inimigos, teriam entendido esses mesmos "comunistas" antes dos bandos armados chegarem? Quer dizer, na constituição do processo de independência, como teria sido a compreensão dessas pessoas que agora estão compondo a "outra margem" diante das mutações políticas? Esses questionamentos entram na malha narrativa, obviamente, não pela ótica das crianças que sequer sabem exatamente onde estão, mas pela ótica do velho Matias e de Malaquias, que acompanharam os dois processos: o da independência, e depois a guerra. Vejamos (OSN, p. 131):

Tudo se fora. Tudo o que de mais belo um ser humano pode almejar retiraram-lhe à base de cartilhas importadas de outras latitudes que não a sua. Tiraram-lhe o valor mais sagrado que os seus antepassados lhe legaram: a humanidade. Nunca precisou de estatísticas de pobreza e riqueza para dar aos seus a mandioca e a batata-doce do crescimento. Nunca pediu livros e teorias de ética para separar o bem do mal na educação dos mais chegados e distantes. Jamais se ajoelhou a alguém para pedir alvíssaras. Hoje, numa margem, dão-lhe palavras, noutra, balas. O que é isto?...

Outra personagem emblemática é Josefina, relembrada num longo diálogo entre Malaquias e Matias. Tratava-se de uma comerciante ambulante que alimentava relações com ambos os lados da guerra. Denunciada por inveja às "autoridades populares" como "infiltrada", Josefina acabou fuzilada. Desde o início, no entanto, quando era considerada uma "falsária", uma "sorrelfa", Josefina tratava de se justificar, recusando essa denominação e percebendo-se a si própria como uma resultante da "dupla existência dos carentes da vida". Podemos ver isso num excerto em que nosso narrador se aproxima tanto da personagem que o turno narrativo se transforma em discurso indireto livre, e ouvimos a própria Josefina a falar (OSN, p. 67):

De cada lado da discórdia falava-se num futuro de bem-estar. E ela não procurava esse futuro. Ela lutava pelo bem-estar do presente dos seus filhos. Se eu fosse a esperar 
pelo futuro feliz com que me enchem os ouvidos, os meus filhos estariam mortos de fome e sede. O meu futuro é o presente feliz que procuro, com sinceridade, obter no meu trabalho de compra e venda.

A história de Rosa, na altura da narrativa com vinte e três anos (OSN, p. 39), e, portanto, um pouco mais velha que os demais do grupo, também é um exemplo do distanciamento entre essas personagens e os processos políticos pré-guerra. Criada por Samuel Nobela, um seu tio, filho de um cipaio, viu um a um dos amigos da aldeia se converterem em algozes inimigos que trataram de o açoitar, considerá-lo publicamente como um reacionário e, de alguma forma, expulsá-lo da vila (OSN, p. 42-44). Mais tarde, viria à aldeia com quarenta homens ao seu comando, armados, devastar a vila. Abandonada pelo tio, no entanto, Rosa fugiu sem rumo da aldeia e transformou-se numa "jovem guerreira de causas desconhecidas" (OSN, p. 53). Alguns trechos desse engaste narrativo, no entanto, são muito salutares para percebermos as relações entre os acontecimentos políticos e a concepção das personagens; quando a instabilidade política começa a ocorrer, por exemplo, e essas notícias chegam à aldeia, podemos ver (OSN., p. 42):

Ouviam-se disparos ocasionais. Falava-se de uma outra luta. Circulavam palavras ornadas com tons não vermelhos. Palavras que confundiam os camponeses, pois contradiziam as que os substitutos de régulos de verdade, com a castanha ou cinzenta farda a que chamavam balalaica, incutiam nos campónios como se sementes fossem, pois era de bom tom dizerem que os bons tempos virão [...]. Mas os bons tempos não vinham, com as prognosticadas palavras $[\ldots]$.

Ou quando Rosa, já alinhada na batalha, teve dificuldades em perceber contra o que lutava, como se vê (OSN, p. 57):

E quando perguntava quem era o inimigo, diziam-lhe uns que era a nação, e outros que eram os da nação. Os da nação 
tinha ela vaga ideia, pois o tio sempre a eles se referia nos seus prolongados monólogos. E imaginava-os como indivíduos de raças desconhecidas, vivendo em casas que nunca imaginara, e com uma prodigiosa, senão sobrenatural, inteligência, pois como era possível que os da nação soubessem da existência do tio e o designassem por reacionário? [...] E quando diziam que combatiam a nação, a sua imaginação alicerçava-se ainda mais na noção de indivíduos incomuns [...]. Meses depois, e em presença de chefes mais graúdos, tomou conta de um adjectivo que criava pânico: comunista.

Diversos outros episódios estão presentes em toda a obra que mostram a ruptura causada pela independência, muito mal compreendida por quase todos as personagens, que se debatem constantemente com os novos termos agora correntes. Outrossim, a própria guerra é já uma grande ruptura, de todo modo, à qual nosso narrador habilmente trata pelo Caos. Não é possível, portanto, afirmar que um macrotema de Os sobreviventes da noite não seja a guerra. Mas, curiosamente, não trata da guerra em si mesma, mas, para tratar dela, prefere verificar como as mudanças políticas e as dinâmicas da guerra se constituem tendo como metro comum as inúmeras histórias individuais que se confluem num fluxo temporal descontínuo, que aglomera diversas camadas de tempo com fundo num presente dependente.

Ora, então temos que nosso presente dependente, que desloca o foco da guerra enquanto fato político nacional e internacional, é uma forma de tratar da guerra. Nesse sentido, quais serão as motivações que levariam nosso romancista a optar por essa estrutura estética para tratar do dado histórico? Será relevante perceber que, ao tratar da guerra, Os sobreviventes da noite desloca o sentido óbvio, alterando o foco das tensões políticas num sentido lato para os sujeitos, num sentido estrito, e cria uma narrativa de presente enfraquecido em detrimento das inúmeras histórias pessoais? $\mathrm{O}$ que isso pode nos dizer em termos de fatura estética relacionada à história de Moçambique? 